\title{
CORROSION BEHAVIOUR OF TIN ELECTRODE IN CITRIC ACID, MALIC ACID AND GLUTAMIC ACID
}

\author{
GOZEN BEREKET AND ARZU YEDIGUN
}

Department of Chemistry, Faculty of Arts and Sciences, University of Anatolia, Eskişehir, Turkey

(Received July 18, 1990; Revised January 26, 1991; Accepted January 31, 1991)

\section{SUMMARY}

Corrosion behaviour of tin in citric acid, malic acid and glutamic acid at pH 2 and pH 6 in the concentration range of $10^{-1} \mathrm{M}-10^{-4} \mathrm{M}$ was investigated. Corrosion potentials were shifted to more negative values with the increasing of citric acid and malic acid concentrations and corrosion rates were increased both at $\mathrm{pH} 2$ and $\mathrm{pH} 6$ Corrosion potentials in glutamic acid at $\mathrm{pH}$ 6 were shifted to noble values with increasing of concentration and this was attributed to the film formation. But no regular change hetween glutamic acid concentration and corrosion rate was observed at $\mathrm{pH} 2$. Order of increasing of corrosion rate of acids were as follows.

$$
\text { Citric acid }>\text { malic aeid }>\text { glutamie acid }
$$

Corrosion rate of tin was increased by the addition of nitrate or nitrite. But accelerating effect of nitrate and nitrite was pronounced at pH 2. Also accelerating effect of nitrite was found to be greater than nitrate.

\section{INTRODUCTION}

The corrosion resistance of tin plate depends upon the interrelationships of the charactenistic of can and the product packed therein. Tin may behave as cathode or anode with respect to steel depending upon the nature of corrosive medium. It is generally believed that the protection offered by tin to steel at the interior surface of tin plated food cans is a sacrifical one. Contrary to its position in the electrochemical series of element which would require tin to be cathodic to iron, the metal becomes the anode in the local electrolytic cell that are set up when tin plate is in contact with the liquid medium of food product. The obse:ved change in polarity is accepted to be related with complexing ability of different organic acids. Corrosion of cans by tomato juice is known to be stimulated mainly by citric acid, malic acid and glutamic acid (Takeuchi, 1978). 
It is well known that nitrite and nitrate are accelerators for the corrosion of tin in organic acid (Board, Holland, 1969; Luft, 1973; Britton, 1973). Thus it was deemed desirable to investigate the corıosion behaviour of tin in citric acid, malic acid and giutamic acid in a wide range of concentration and $\mathrm{pH}$ values. The accelerating effect of nitrates and nitrites on dissolution of tin plated can of acid products has been investigated through canned model experiments by solution analysis (Yaron and Samuel, 1976).

Systematic investigation correlating the increasing corrosive offect of nitrate and nitrite in citric acid, malic acid and glutamic acid needed to be studied by electrochemical technique. This study was thought to be essential to help in understanding the corrosion mechanism of food system.

\section{EXPERIMENTAL METHODS}

Solutions of citric acid, malic acid and glutamic acid were prepared using double distilled water. The $\mathrm{pH}$ of solutions were adjusted by adding small increments of sodium hydroxide or perchloric acid and checked with $\mathrm{pH}$-meter. All chemicals used were of Merck quality, nitrite and nitrate were introduced in the form of $\mathrm{KNO}_{2}$ and $\mathrm{NaNO}_{3}$. Polarization experiments were carried out in electrolytic cell that was provided with an inlet and outlet to permit deaeration by passing nitrogen gas through the test solution before each measurement. A platinum counter electrode and saturated calomel electrode as reference electiode were used. Tin electrode was prepared from pure tin rods. A constant predermined area of $86.5 \mathrm{~mm}^{2}$ was exposed to the test solution. Potentiodynamic polarization curve were obtained using Tacusel PRG-5 polarographic analyzer.

\section{RESULTS AND DISGUSSION}

Cathodic polarization curves in deareated citric acid, malic acid and glutamic acid solutions obtained when tin electrode was polarized from corrosion potential in cathodic direction at a scan rate of $2 \mathrm{mV} / \mathrm{sec}$ did not exhibit normal Tafel line. But shoulder region just negative to the corrosion potential was observed. This shoulder did not occur when tin electrode was precathodized for 5 minutes at $-900 \mathrm{mV}$.

The shoulder which was observed just negative to the conosion potentials appearently represents the reducible form of tin oxide which was reduced when tin electrode was precathodized for 5 minutes at -900 
mV (S.C.E.). Same situation was observed by Henry Leidheiser and A. Rauch (Leidheiser, et. al., 1981) in polarization of tin electrode in deaerated $0.33 \mathrm{M}$ citric acid solutions.

Cathodic polarization curve in deaerated $10^{-1} \mathrm{M}$ citric acid at $\mathrm{pH}$ 6 is shown in Figure (1) by curve (a). Cathodic polarization curve in $10^{-1}$ $\mathrm{M}$ citric acid at $\mathrm{pH} 6$ obtained when tin electrode was precathodized for 5 minutes at $-900 \mathrm{mV}$ is shown in Figure (1) by curve (b). In (Fig. 2), (Fig. 3) and (Fig. 4) cathodic polarization curves in citric acid at pH 6 in concentration range of $10^{-1} \mathrm{M}-10^{-4} \mathrm{M}$ cathodic polarization curve in malic acid at $\mathrm{pH}$ in concentration range of $10^{-1} \mathrm{M}-10^{-4} \mathrm{M}$ and cathodic polarization curves of glutamic acid at $\mathrm{pH} 6$ in concentration region of $10^{-1} \mathrm{M}-10^{-4} \mathrm{M}$ are given respectively. Cathodic polarization curves in citric acid, malic acid and glutamic acid in the concentration range of $10^{-1} \mathrm{M}-10^{-4} \mathrm{M}$ at pH 2 are shown in (Fig. 5), (Fig. 6) and (Fig. 7) respectively.

Corrosion currents were obtained by extrapolating the cathodic polarization (Tafel line) to the predetermined steady state open circuit Fotential. The summary of the results obtained in citric acid, malic acid and glutamic acid at $\mathrm{pH} 6$ and $\mathrm{pH} 2$ are listed in Table 1 and Table 2 respectively. Corrosion currents in all acid solutions at $\mathrm{pH} 6$ and $\mathrm{pH} 2$

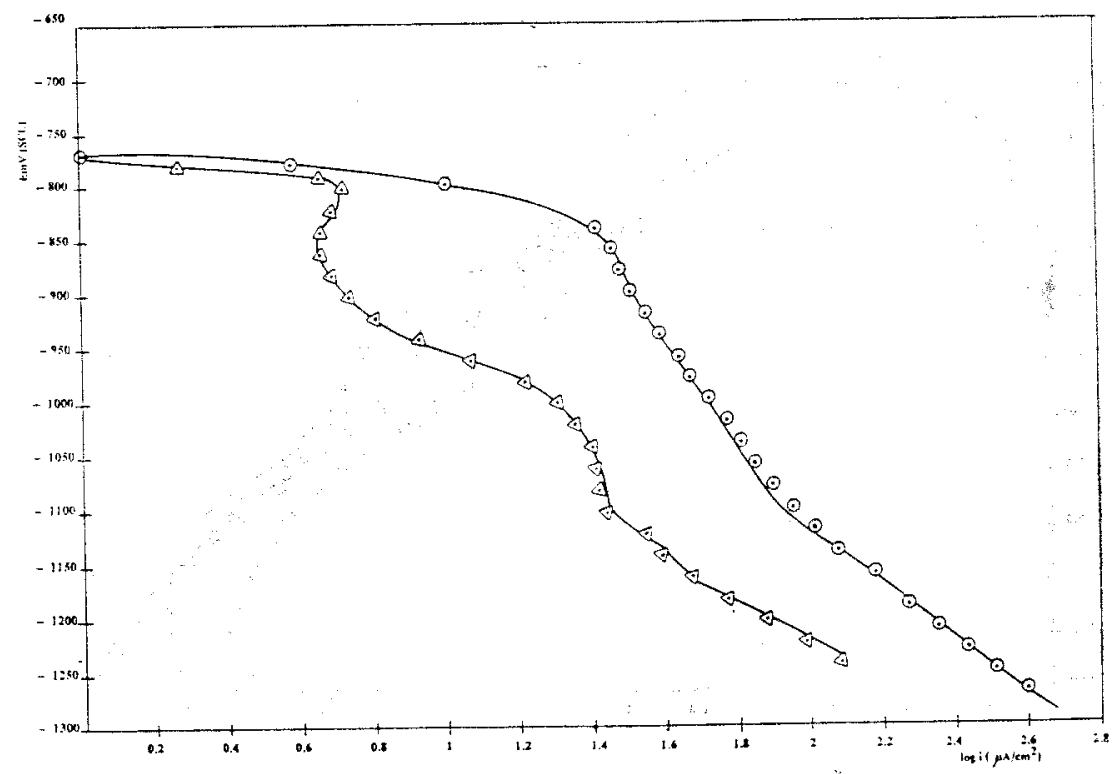

Figure 1. Cathodic polarization curves of tin in deaerated $10^{-1}$ M citric acid solutions at pH 6. 


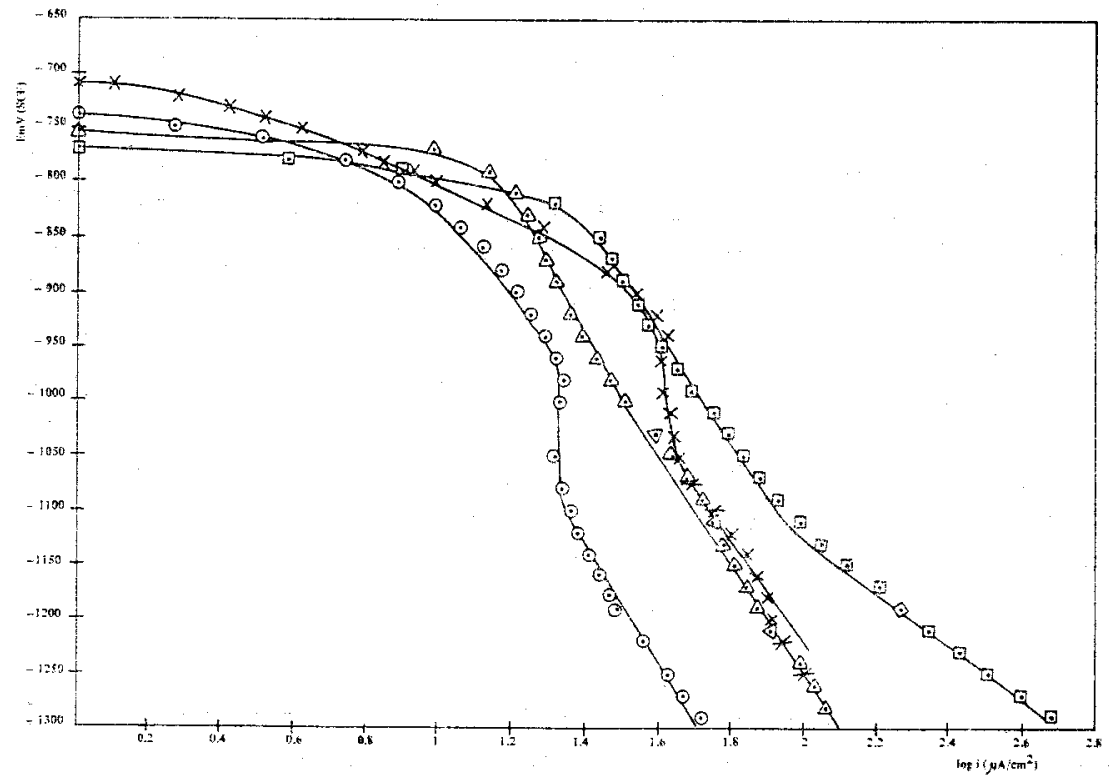

Figure 2. Cathodic polarization curve of tin in deacrated citric acid solutions at pH 6.

$$
\square^{10^{-1} \mathrm{M}} \quad \triangle 10^{-2} \mathrm{M} \quad \bigcirc^{10^{-3} \mathrm{M}} \times 10^{-4} \mathrm{M}
$$



Figure 3. Cathodic polarization curve of tin in deaerated malic acid solutions at $\mathrm{pH} 6$.

$$
\square 10^{-1} \mathrm{M} \quad \triangle 10^{-2} \mathrm{M} \quad \bigcirc^{10^{-3} \mathrm{M}} \quad \times 10^{-4} \mathrm{M}
$$




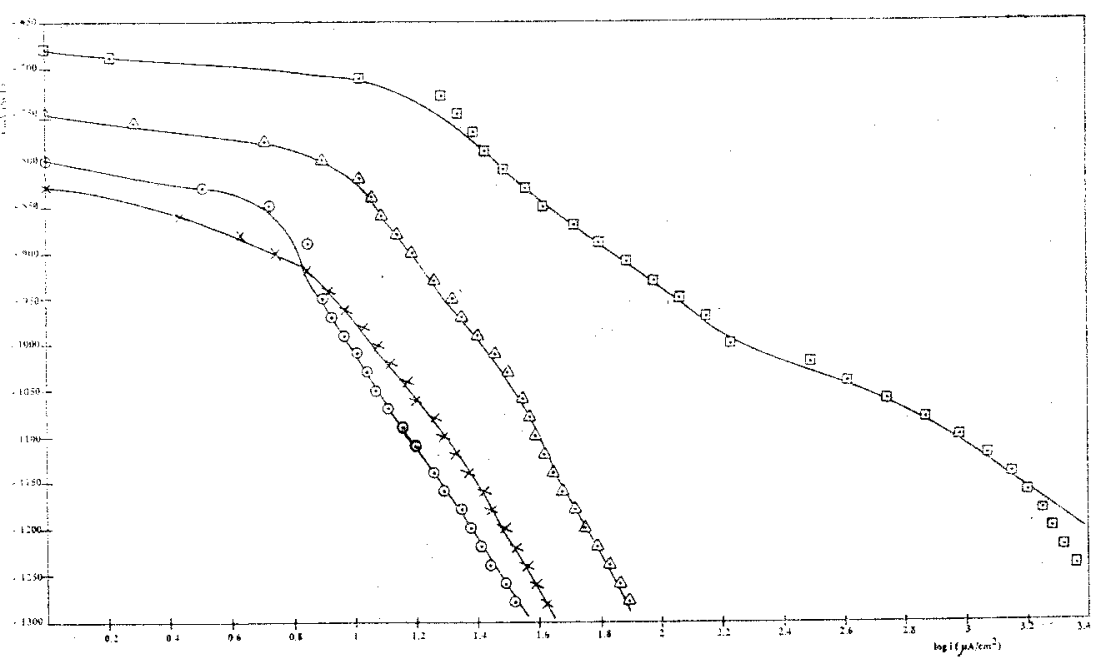

Figure 4. Cathodic polarization curve of tin in deaerated glutamic acid solutions at pH 6 . []$^{-1} \mathrm{M} \quad \triangle 10^{-2} \mathrm{M} \quad \bigcirc^{10^{-3} \mathrm{M}} \quad \times 10^{-4} \mathrm{M}$

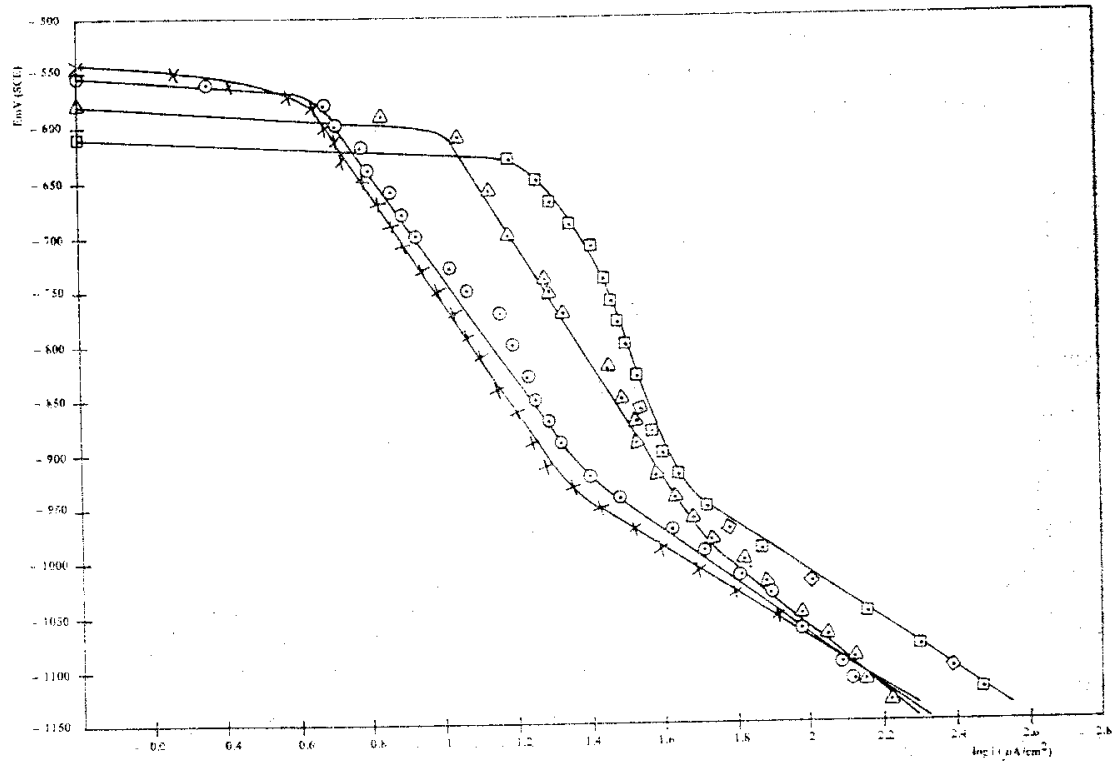

Figure 5. Cathodic polarization curve of tin in deaerated citric acid solutions at pH 2 . $\left[10^{-1} \mathrm{M} \quad \triangle 10^{-2} \mathrm{M} \quad \mathrm{O}^{10^{-3} \mathrm{M}} \times 10^{-4} \mathrm{M}\right.$ 


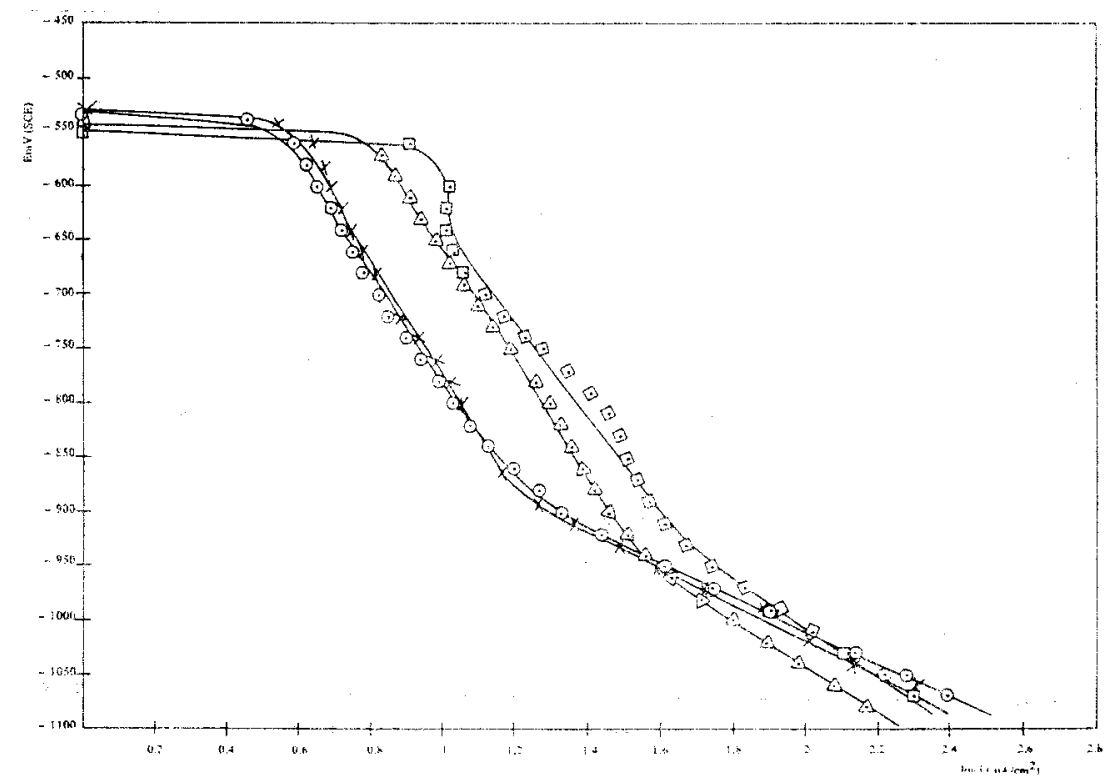

Figure 6. Cathodic polarization curve of tin in deaerated malic acid solutions at pH 2. $\square 10^{-1} \mathrm{M} \quad \triangle^{10^{-2} \mathrm{M}} \quad \bigcirc^{10^{-3} \mathrm{M}} \times 10^{-4} \mathrm{M}$

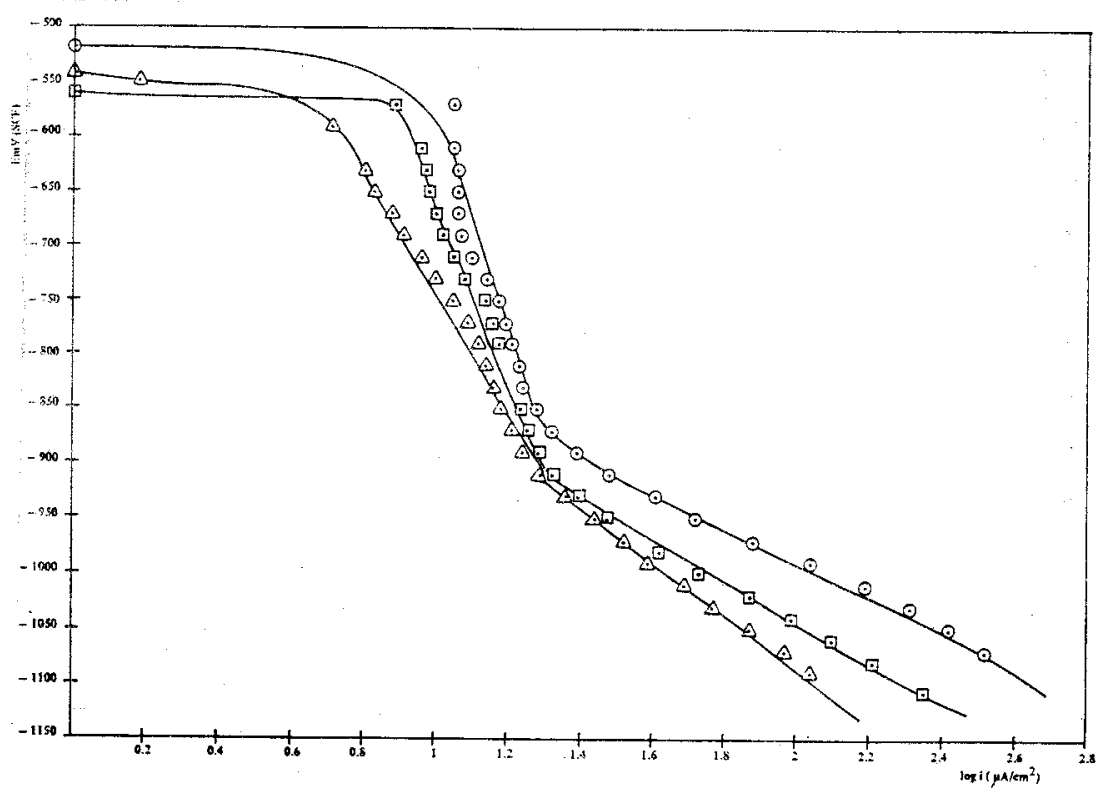

Figure 7. Cathodic polarization curves of tin in deaerated glutamic acid solutions at pH 2. $\square 10^{-1} \mathrm{M} \quad \mathrm{A1}^{10^{-2} \mathrm{M}} \quad \bigcirc^{10^{-9} \mathrm{M}} \times 10^{-4} \mathrm{M}$ 
Table 1. Corrosion Potentials and Corrosion Currents for Tin in Citric Acid, Malic Acid and Glutamic Acid at pH 6.

\begin{tabular}{|l|c|c|c|}
\hline Acid & Concentration (M) & Ecorr $(\mathrm{mV})$ & Ieorr $\left(\mu \mathrm{A} / \mathbf{c m}^{2}\right)$ \\
\hline Citric Acid & $10^{-1}$ & -770 & 18.62 \\
& $10^{-2}$ & -755 & 13.80 \\
Malic Acid & $10^{-3}$ & -740 & 6.76 \\
& $10^{-4}$ & -695 & 1.99 \\
& $10^{-1}$ & -725 & 14.12 \\
Ghutamic Acid & $10^{-2}$ & -620 & 3.71 \\
& $10^{-3}$ & -595 & 1.51 \\
& $10^{-4}$ & -510 & 1.32 \\
& $10^{-1}$ & -680 & 10.96 \\
& $10^{-2}$ & -750 & 6.61 \\
& $10^{-3}$ & -800 & 4.17 \\
\hline
\end{tabular}

Table 2. Corrosion Potentials and Corrosion Currents for Tin in Citric Acid, Malic Acid and Glutamic Acid at $\mathrm{pH} 2$.

\begin{tabular}{|l|c|c|c|}
\hline Acid & Concentration (M) & Ecorr (mV) & Icorr $\left(\mu \mathrm{A} / \mathrm{cm}^{2}\right)$ \\
\hline Gitric Acid & $10^{-1}$ & -610 & 20.42 \\
& $10^{-2}$ & -585 & 10.00 \\
$10^{-3}$ & -555 & 4.79 \\
Malic Acid & $10^{-4}$ & -545 & 3.80 \\
& $10^{-1}$ & -550 & 12.59 \\
& $10^{-9}$ & -545 & 6.02 \\
Glutamic Acid & $10^{-3}$ & -530 & 4.78 \\
& $10^{-4}$ & -525 & 3.89 \\
& $10^{-1}$ & -560 & 7.76 \\
& $10^{-2}$ & -545 & 4.26 \\
$10^{-3}$ & -520 & 9.33 \\
$10^{-4}$ & -510 & not ab!e to \\
& & & be computed \\
\hline
\end{tabular}

containing $10^{-3} \mathrm{M}$ nitrate were obtained by polarization resistance method by taking value of $\beta=-26 \mathrm{mV}$. In the same way corrosion currents in all acid solutions at $\mathrm{pH} 6$ and $\mathrm{pH} 2$ containing $10^{-3} \mathrm{M}$ nitrite were obtained by polarization resistance method taking value of $\beta=26 \mathrm{~m}$. Attempts were made to obtain typical Tafel line by cathodic polarization in acid solutions containing nitrate or nitrite by precathodization period of 5 minutes at $-900 \mathrm{mV}$. But there was no success. The curves had the shape of cathodic passivity curve described previously by Clarke and Bernie (Clarke and Bernie, 1967), The tentative interpretation of this behaviour is that at potential up to approximately $200 \mathrm{mV}$ negative of the corrosion potential the surface of tin is partially covered with a tin oxide resulting from the oxidizing character of nitrate and nitrite.

Corrosion currents in acid solutions at $\mathrm{pH} 6$ and $\mathrm{pH} 2$ containing $10^{-3} \mathrm{M}$ nitrate or nitrite are given in Table (3), Table (4), Table (5), 
Table 3. Corrosion Potentials and Corrosion Currents for Tin in Citric Acid, Malic Acid and Glutamic Acid Solutions Containing $10^{-3} \mathrm{M} \mathrm{NaNO}_{3}$ at $\mathrm{pH} 6$.

\begin{tabular}{|l|c|c|c|}
\hline Acid & Concentration (M) & Error $(\mathrm{mV})$ & Icorr $\left(\mu \mathrm{I} / \mathrm{cm}^{2}\right)$ \\
\hline Citric Acid & $10^{-1}$ & -760 & 19.07 \\
& $10^{-2}$ & -750 & 13.6 \\
$10^{-3}$ & -760 & 5.2 \\
Malic Acid & $10^{-4}$ & -685 & 2.23 \\
& $10^{-1}$ & -760 & 16.40 \\
& $10^{-2}$ & -770 & 5.77 \\
Glutanic Acid & $10^{-3}$ & -745 & 3.28 \\
& $10^{-4}$ & -735 & 3.58 \\
& $10^{-1}$ & -780 & 8.84 \\
& $10^{-3}$ & -840 & 10.00 \\
& $10^{-3}$ & -820 & 3.50 \\
\hline
\end{tabular}

Table 4. Corrosion Potentials and Corrosion Currents for Tin in Gitric Acid, Malic Acid and Glutamic Acid Solutions Containing $10^{-3} \mathrm{M}$ NaNO at $\mathrm{pH} 2$.

\begin{tabular}{|l|c|c|c|}
\hline Acid & Concentration (M) & Ecorr (mV) & Icorr $\left(\mu \mathrm{A} / \mathrm{cm}^{2}\right)$ \\
\hline Citric Acid & $10^{-1}$ & -600 & 35.36 \\
& $10^{-2}$ & -575 & 24.96 \\
Malic Acid & $10^{-3}$ & -550 & 20.8 \\
& $10^{-4}$ & -510 & 8.91 \\
& $10^{-1}$ & -530 & 60.00 \\
Glutamic Acid & $10^{-2}$ & -515 & 46.43 \\
& $10^{-3}$ & -495 & 31.20 \\
& $10^{-4}$ & -470 & 23.26 \\
& $10^{-1}$ & -510 & 82.20 \\
& $10^{-2}$ & -450 & 68.25 \\
& $10^{-3}$ & -430 & 40.86 \\
\hline
\end{tabular}

Table 5. Corrosion Potentials and Corrosion Currents for Tin in Citric Acid, Malic Acid and Chtamic Acid Solutions Containing $10^{-3} \mathrm{M}$ KNO2 at pH 6 .

\begin{tabular}{|l|c|c|c|}
\hline Acid & Concentration (M) & Ecorr $(\mathrm{mV})$ & Icorr $\left(y / \mathrm{Alm}^{2}\right)$ \\
\hline Citric Acid & $10^{-1}$ & -770 & 10.00 \\
& $10^{-2}$ & -750 & 12.29 \\
\multirow{3}{*}{ Malic Acid } & $10^{-3}$ & -740 & 5.72 \\
& $10^{-4}$ & -650 & 1.25 \\
& $10^{-1}$ & -760 & 19.76 \\
Glutamic Acid & $10^{-2}$ & -785 & 6.42 \\
& $10^{-3}$ & -825 & 5.20 \\
& $10^{-4}$ & -820 & 3.80 \\
& $10^{-1}$ & -850 & 5.81 \\
& $10^{-2}$ & -820 & 6.12 \\
& $10^{-3}$ & -790 & 4.04 \\
\hline
\end{tabular}


Table (6) respectively. Typical linear current potential curves for these solutions are given in (Fig. 8) and (Fig. 9) respectively.

Table 6. Corrosion Potentials and Corrosion Currents for Tin in Citric Acid, Malic Acid and Glutamic Acid Solutions Containing $10^{-3} \mathrm{M} \mathrm{KNO} 2$ at $\mathrm{pH} 2$.

\begin{tabular}{|l|c|c|c|}
\hline Acid & Concentration (M) & Ecorr $(\mathrm{mV})$ & Icorr $\left(\mu \mathrm{A} / \mathrm{cm}^{2}\right)$ \\
\hline Gitric Acid & $10^{-1}$ & -555 & 60.66 \\
& $10^{-2}$ & -525 & 91.00 \\
& $10^{-3}$ & -490 & 83.20 \\
Malic Acid & $10^{-2}$ & -480 & 80.00 \\
& $10^{-1}$ & -530 & 75.83 \\
& $10^{-2}$ & -510 & 52.00 \\
Glutamic Acid & $10^{-3}$ & -490 & 32.12 \\
& $10^{-4}$ & -475 & 17.79 \\
& $10^{-1}$ & -530 & 110.5 \\
& $10^{-2}$ & -480 & 64.00 \\
& $10^{-3}$ & -460 & 72.22 \\
\hline
\end{tabular}

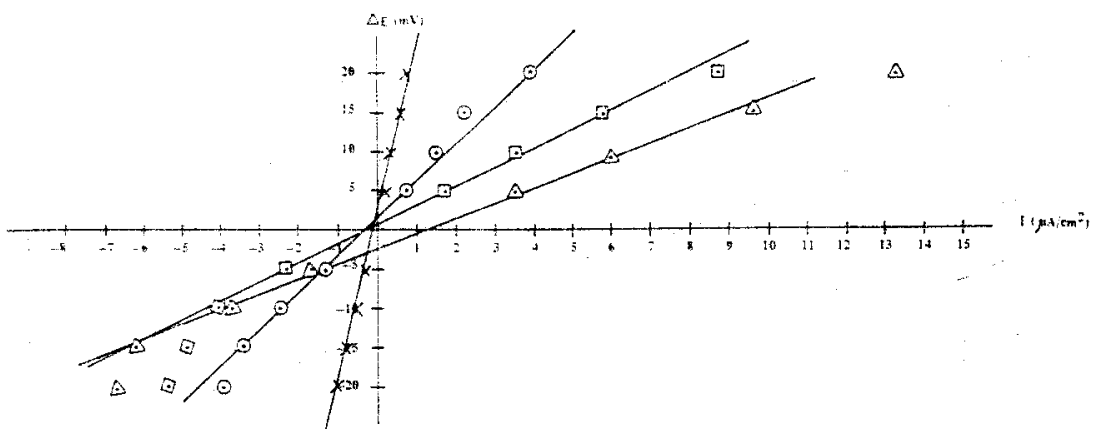

Figure 8. Linear polarization curves in deaerated citric acid solutions containing $10^{-3} \mathrm{M}$ nitrite at $\mathrm{pH} 6$.

$\square 10^{-1} \mathrm{M} \quad \triangle 10^{-2} \mathrm{M} \quad \mathrm{O}^{-3} \mathrm{M} \quad \times 10^{-4} \mathrm{M}$

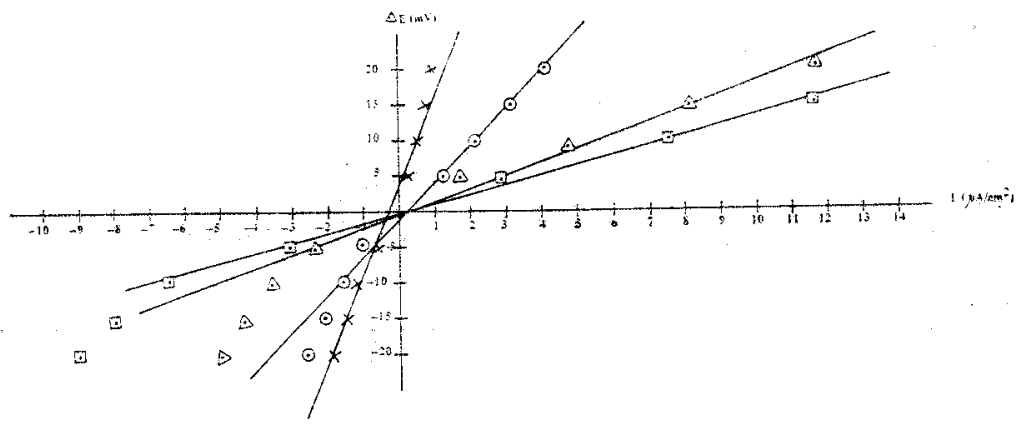

Figure 9. Linear polarization curves in deaerated citric acid solutions containing $10^{-3} \mathrm{M}$ nitrate at pH 6.

$$
\square^{10^{-1} \mathrm{M}} \quad \mathrm{A10}^{-2} \mathrm{M} \quad \mathrm{O}^{-3} \mathrm{M} \quad \times 10^{-4} \mathrm{M}
$$


Plots of corrosion potentials as a function of the logarithm of acid concentrations are shown in (Fig. 10), (Gig. 11), (Fig. 12) for citric acid, malic acid and glutanic acid respectively. At $\mathrm{pH} 6$ and $\mathrm{pH} 2$ linear relationship holds between corrosion potentials and logarithm of the acid concentrations. Except for glutamic acid at pH 6 corrosion potentials are shifted towards more negative values with the increasing of acid concentrations. For glutamic acid at $\mathrm{pH} 6$ change of corrosion potential towards more positive values signifies the film formation (Evans, 1968). This film formation is probably resulted from the hydıolysis of glutamic acid-tin complex near the neutral solutions (Shrier, 1977). Shifting towards more negative values in corrosion potential with increasing acid

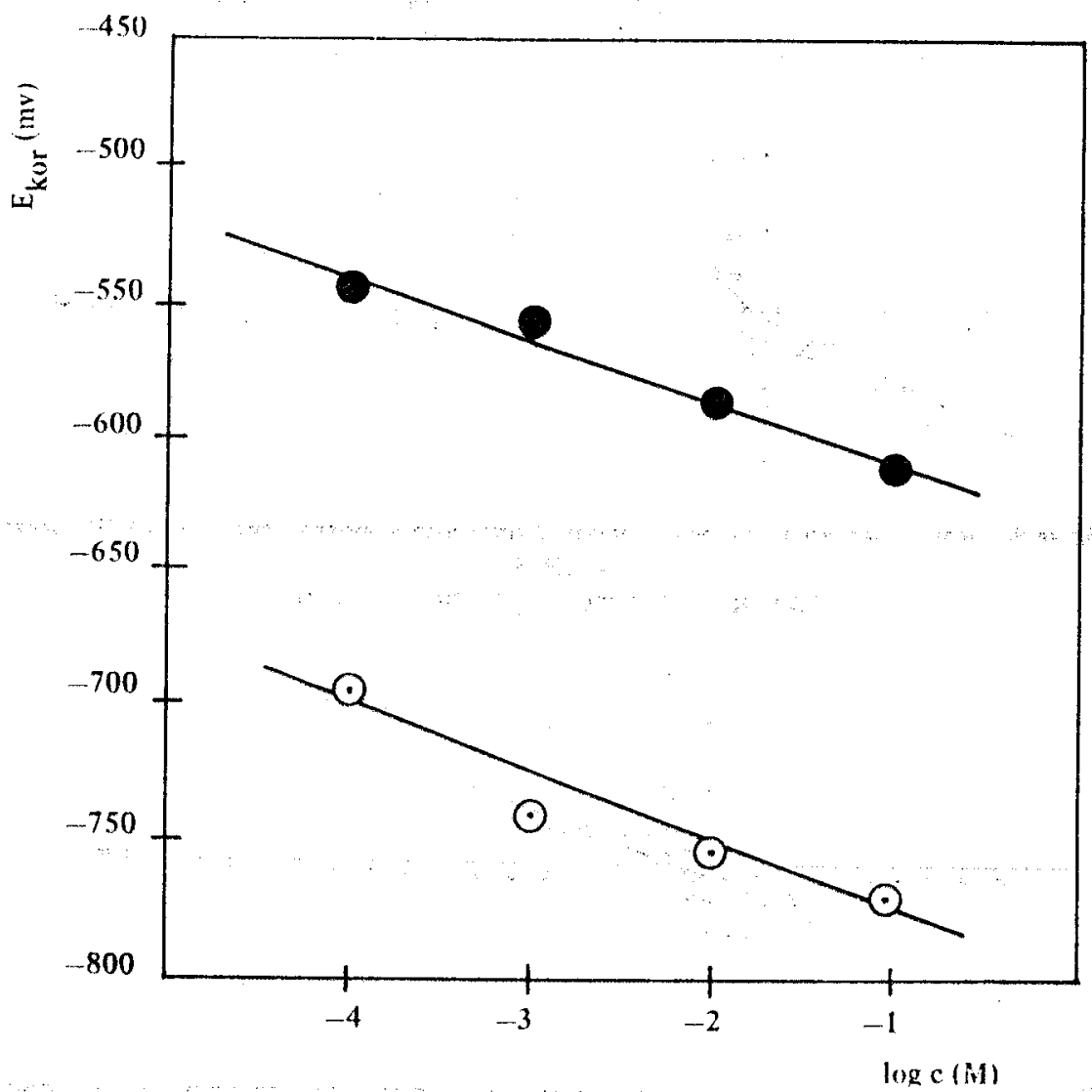

Figure 10. The variation of corrosion potentials with the logarithm of citric acid concentrations. OpH2 OpH 6 


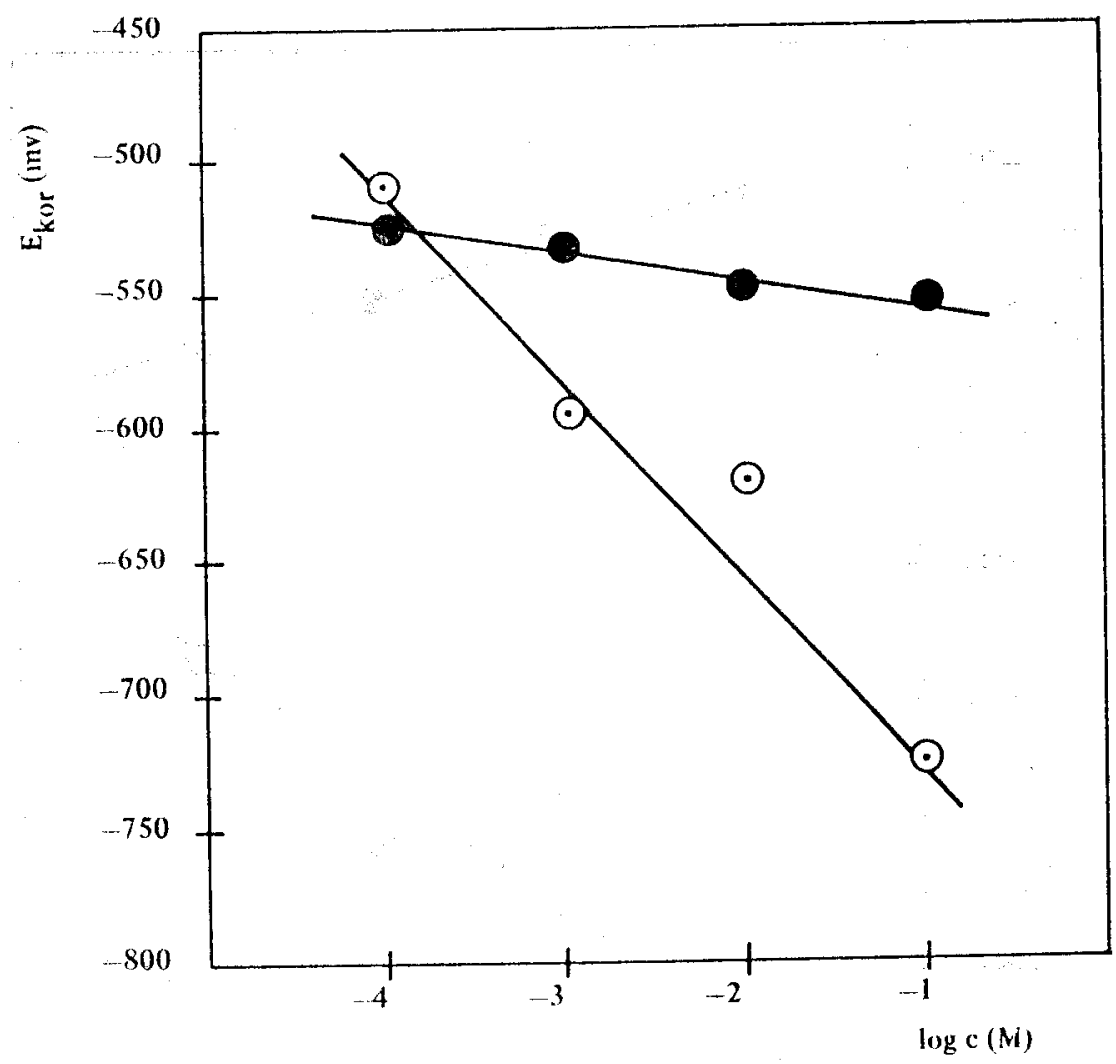

Figure 11. The variation of corrosion potentials with the logarithm of malic acid concentr $t$ 'ons. $\mathrm{pH} 2 \mathrm{OpH} 6$

concentration at $\mathrm{pH} 6$ and $\mathrm{pH} 2$ in citric acid and malic acid accompanied by simultaneous increase in the corrosion rate of tin. All these results suggest that the corrosion of tin in these solutions is anodically controlled (Gouda, et., el., 1981).

In ghutamic acid at $\mathrm{pH} 2$ there was not regular jncrease in corrosion currents with increasing of acid concentration. This disagreement may be due to competition between the film formation and complex formation effect of glutamic acid.

Citric acid has the following structure and might act as tetradentate ligand towards $\mathrm{Sn}^{2+}$ ion..... 


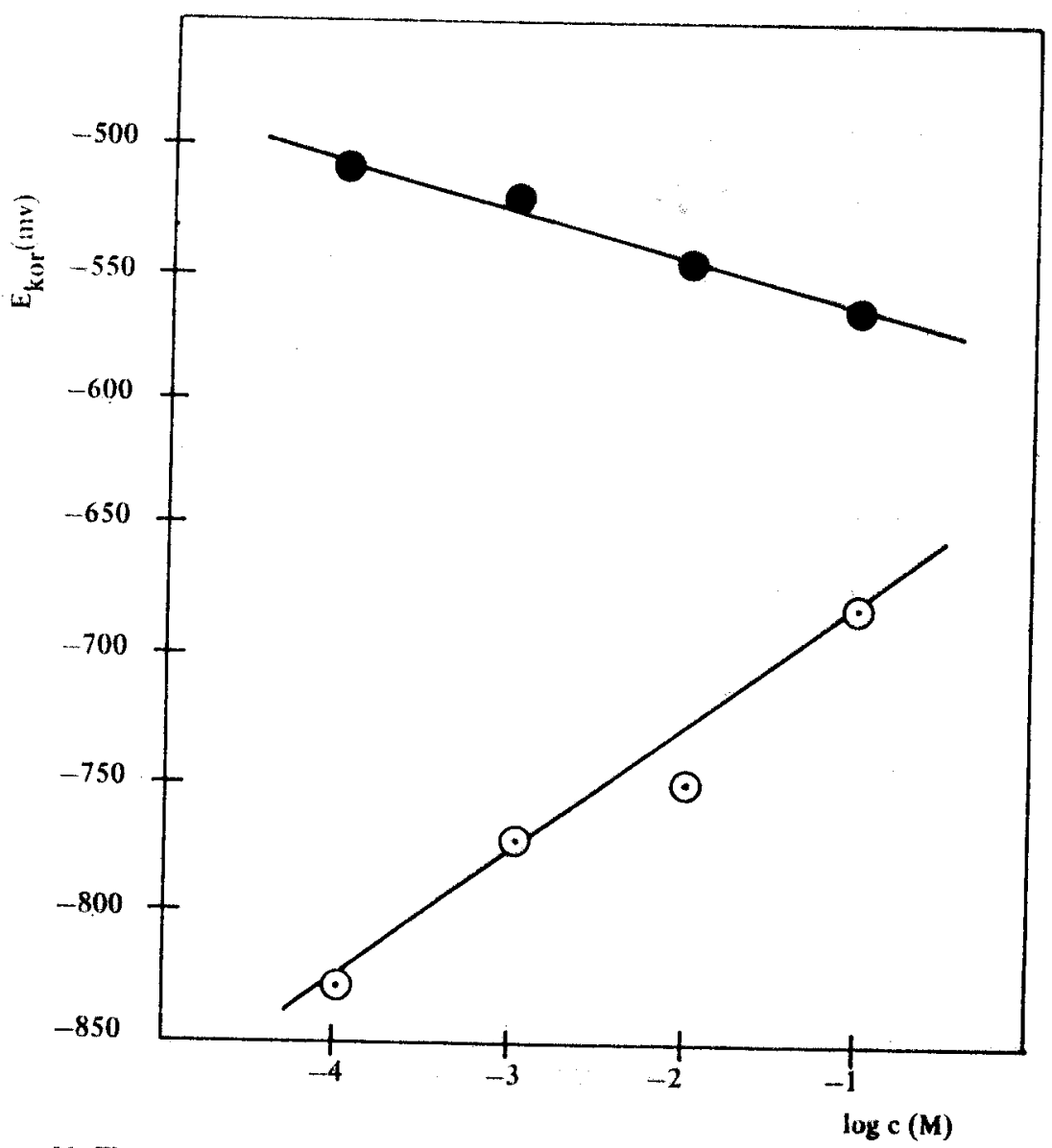

Figure 12. The variation of corrosion potentials with the logaritha of glatamic acid concentra. tions.

OpH 2 CpH 6

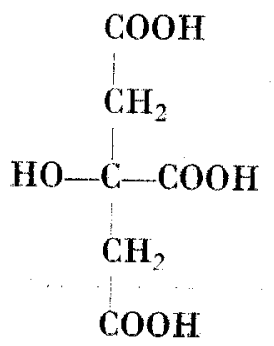


While malic acid has the following structure which acts as tridentate ligand (Smith, 1961). It has been suggested that tin $\mathrm{Sn}^{2+}$ is fourcoordinated in certain chelates and pid hybrid orbitals are involved in bonding (Smith, 1961).

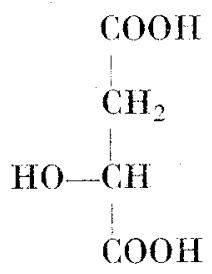

Thus citric acid forms $1: 1$ chelates while malic acid forms $\mathrm{St}\left(\mathrm{H}_{2} \mathrm{O}\right)$ L type complexes. That is three of the four sites around the central metal ion are occupied by malic acid fourth side hy water. Certainly citric acid forms more stable complex. On the other hand glutamic acid acts as tridentate ligand towards $\mathrm{Sn}^{2}$ and has the following structure.

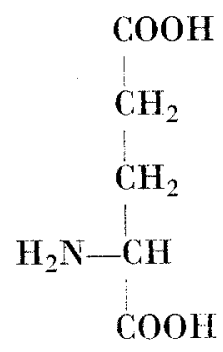

Difference between malic acid and glutamic acid is that two electron rich groups are separated by two $-\mathrm{CH}_{2}$ group this might cause the tin-glutamic acid complex to be less stable than tin-malic acid complex. In addition amine groups has inhibition action for many metals (Hluchan, et al. 1988). Corrosion rate of tin in three acid solution in $10^{-1}$ $M$ concentration is as follows

$$
\text { citric acid }>\text { malic acid }>\text { glutamic acid }
$$

This order is parallel of stability order to tin-acid complex. As it is seen from Table (1), Table (3) and Table (5) increase in corrosion rate by the addition of nitrite or nitrate in citric acid, malic acid, glutamic acid at $\mathrm{pH} 6$ is not as much to be considered. These results are consistent with the corrosion tate of tin plated ean in organic acid containing nitrite or nitrate at $\mathrm{pH} 6$ which the corrosion rates were determined by solution analysis (Farrow et al., 1970). 
But addition of $10^{-3} \mathrm{M}$ nitrate or nitrite to the different concentration of citric acid, malic acid and glutamic acid at $\mathrm{pH} 2$ incerases corrosion rate of tin very much as it is seen in Table (2), Table (4) and Table (6). Acceleration effect of nitrate or nitrite in organic acid for the corrosion of tin may be due to electron accepting effect of nitrite or nitrate when tin dissolves. In this way, nitrite or nitrate increases the rate of cathodic reaction, thus corrosion rate.

Electron accepting reactions of nitrate or nitrite are the followings and occur in acidic solutions.

$$
\begin{aligned}
& \mathrm{NO}_{3}^{--}+3 \mathrm{H}^{+}+2 \mathrm{e}^{-} \rightleftarrows \mathrm{HNO}_{2}+\mathrm{H}_{2} \mathrm{O} \\
& \mathrm{NO}_{3}^{--}+4 \mathrm{H}^{+}+3 \mathrm{e}^{-} \rightleftarrows \mathrm{NO}+2 \mathrm{H}_{2} \mathrm{O} \\
& \mathrm{HNO}_{2}+\mathrm{H}^{+}+\mathrm{e}^{-} \rightleftarrows \mathrm{NO}+\mathrm{H}_{2} \mathrm{O} \\
& \mathrm{NO}_{3}^{-}+10 \mathrm{H}^{+}+8 \mathrm{e}^{--} \rightleftarrows \mathrm{NH}_{4}^{+}+\mathrm{H}_{2} \mathrm{O}
\end{aligned}
$$

Reduction of nitrate to nitrite is slow and is the rate determining step. But reduction of nitrite to ammonia is very rapid. That is why corrosion rate is higher in nitrite containing solutions.

\section{REFEREYCES}

1. ALBU-YARON, A. and SAMUEL, A. J. Agric. Food Chem. 24, 344: (1976).

2. BOARD, P. W. and Folland, R.V. Br. Corros. J. 4, 162 (1969).

3. BRITTON, J. Br. Corros. J. 8, 210 (1974).

4. BRITZ, D. and LUFT, H. Werkstoffe und Korrosion 24, 296 (1973).

5. CLARKE, M. and BERNIE, J.A. Electrochim. Acta 12, 205 (1967).

6. EVANS, V.R. The Corrosion and Oxidation of Metals, Edward Anold (London), p. 898 (1968)

7. FARROW, R.P.; LAO, N.T. and KIM, E.S. J. Food Sci. 35, 818 (1970).

8. GOUDA, V.K.; RIZKALLA, E.N.; ABD.EL WAHAB and IBRAHIM, E.M. Corrosion 4, 1 (1981).

9. HLUCHAY, V; WHEEIEN and HACKERMAN, N. Werkstroffe und Korrosion 39,512 (1988).

10. LEWHEISER, H.; ALTON, Jr; RAUCH, F.: ELHOSENY, M.; IBRAHTM and RICHARD D. GRANATA J. Electrochem. Soc. 129, 1651 (1982)

11. SHRTER, L.L. Corrosion, vol. 1, Ch. 4, p. 143 Butterworth, London (1977).

12. SMITH, T.D. J. Chem. Soc. 2554 (1961).

13. TAKEUCHI, O.H. Chemical Abstracts, 91, 122374 z (1978). 